\title{
The Asian Drivers and Sub-Saharan Africa
}

\section{Rhys Jenkins and Chris Edwards*}

\section{Introduction}

In recent years, the two largest countries in Asia, China and India have become increasingly important players in the global economy. Their rapid growth and increased openness since 1990 has led to concerns in both developed and developing countries, but up to now relatively little attention has been paid to their impact on the countries of sub-Saharan Africa, despite the fact that trade between the Asian Drivers ${ }^{1}$ and Africa has grown significantly since 1990 and that in the last few years, China and India have also emerged as sources of foreign direct investment (FDI) in the region.

The direct impacts of the growth of China and India on Africa can take a number of different forms. First, there may be an increase in exports from Africa to the two Asian economies. Second, African imports from China and India are likely to increase significantly. Third, there may be increased competition between the Asian Drivers and some African economies in third markets which could

Figure 1: Africa's trade with China and India, 1990-2003

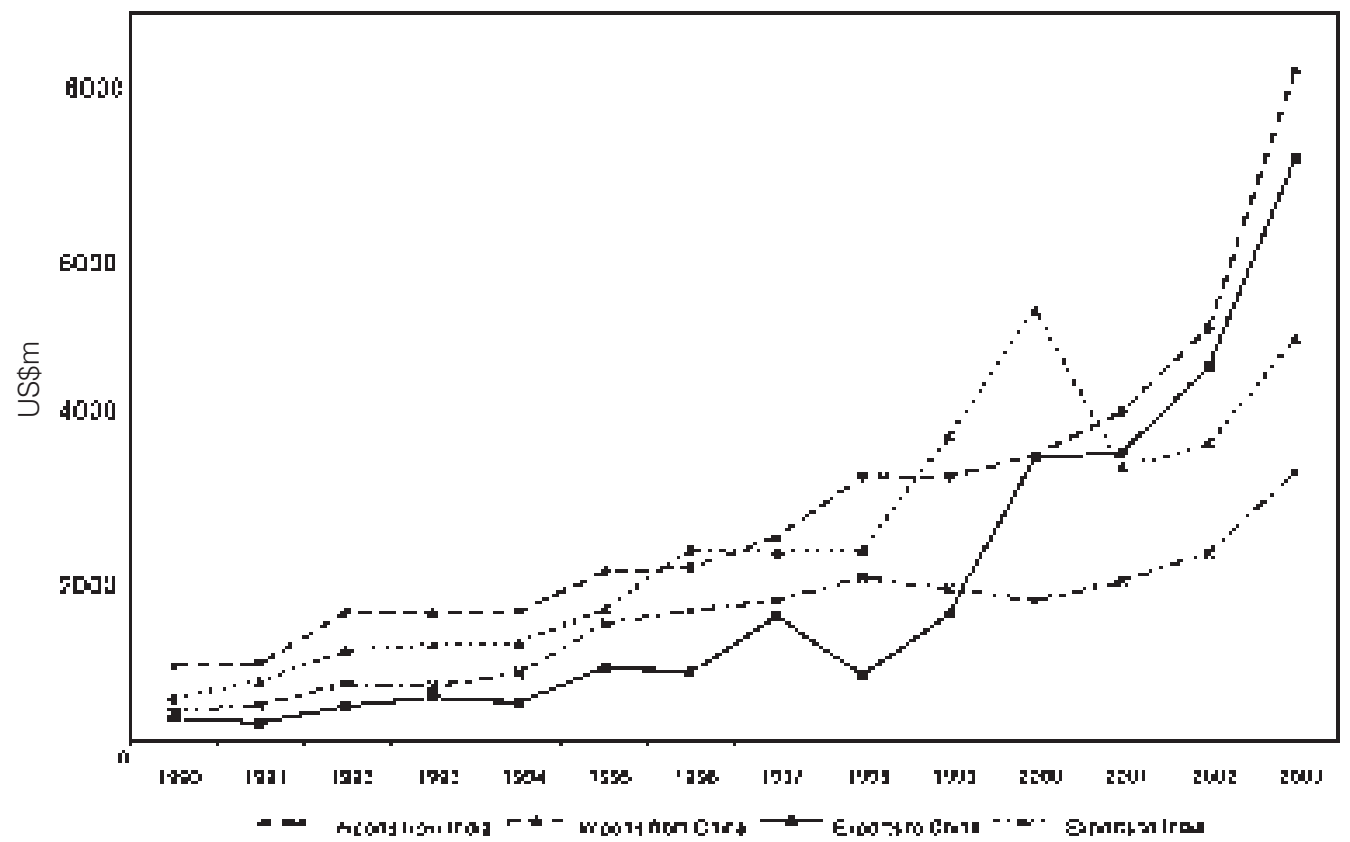

Source: IMF, Direction of Trade Statistics (ESDS International, University of Manchester).

IDS Bulletin Vol 37 No 1 January 2006 @ Institute of Development Studies 


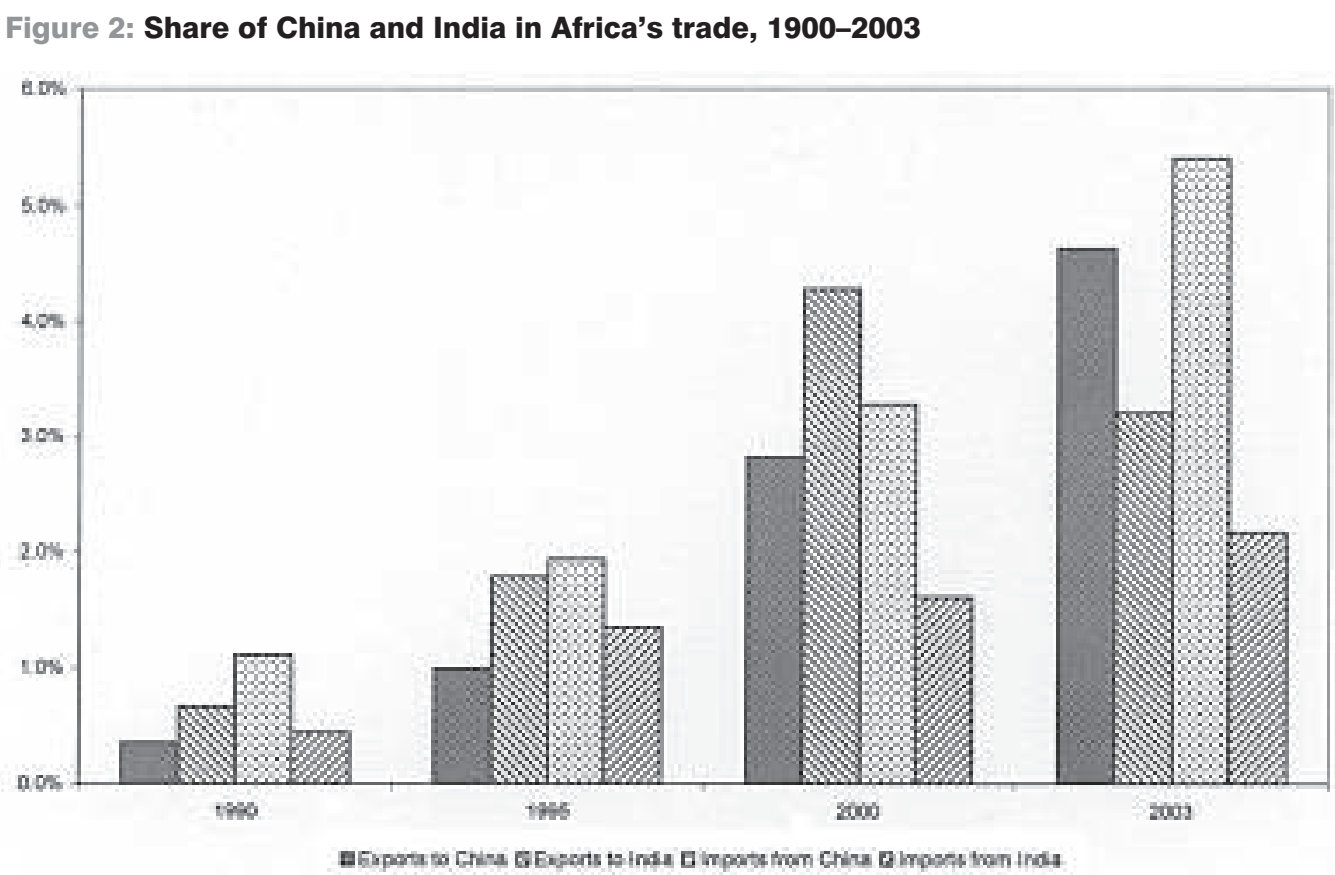

Source: IMF, Direction of Trade Statistics (ESDS International, University of Manchester).

have a negative impact on African exports. Finally, there may be effects on foreign direct investment to Africa, either negative if investment from third countries is diverted to China or India, or positive if China and India become significant sources of FDI in Africa.

There may also be indirect impacts of China and India's growth on the African economies. For example, the increased demand in the Asian economies for imports from developed countries has multiplier effects in those countries which in turn lead to more demand in the developed countries for African exports. Alternatively, the growth of demand for primary commodities in China and India may push up prices which benefit primary commodity exporters, even if they do not have any direct exports to those countries, but can also be a disadvantage for other developing countries who are net importers of the products concerned. These indirect impacts are beyond the scope of this article, which sets out to document the major direct impacts of the Asian Drivers on 21 sub-Saharan countries.

\section{China and India's economic relations with Africa}

Economic links between China and India are not new but both countries' trade with Africa has increased significantly in recent years.

Figure 1 shows the growth of total trade between Africa and the Asian Drivers since 1990. This shows a slow growth in the first half of the 1990s, which accelerated during the second half of the decade particularly after 1998 . Since 2000 , China has overtaken India as a trade partner for Africa. Figure 1 also indicates that whereas Africa has always had a trade surplus with India, it has run a deficit with China, although this has narrowed considerably since 1998 as a result of the rapid growth of exports to China.

Figure 2 illustrates trade with China and India as a share of Africa's total trade over the same period. The relative significance of both exports and imports between Africa and the two Asian economies increased substantially over the period, although the share of Africa's exports going to India fell between 2000 and 2003.

In addition to trade, there is a history of Indian 
Table 1: Share of China and India in exports of 21 African countries, 2003 (\%)

\begin{tabular}{llll}
\hline & China & India & Total \\
\hline Angola & 23.2 & 0.0 & 23.2 \\
Botswana & 0.1 & 0.0 & 0.1 \\
Cameroon & 4.4 & 0.3 & 4.7 \\
Congo (Democratic Republic of) & 2.2 & 0.0 & 2.2 \\
Ethiopia & 0.7 & 1.2 & 1.9 \\
Ghana & 1.6 & 1.3 & 2.9 \\
Kenya & 0.3 & 1.4 & 1.7 \\
Lesotho & 0.0 & 0.0 & 0.0 \\
Malawi & 0.0 & 0.7 & 0.7 \\
Mozambique & 2.3 & 2.1 & 4.4 \\
Namibia & 0.1 & 2.9 \\
Nigeria & 2.9 & 9.9 & 10.4 \\
Rwanda & 0.5 & 0.0 & 4.2 \\
Senegal & 4.2 & 13.0 & 14.4 \\
Sierra Leone & 1.4 & 4.0 & 4.0 \\
Somalia & 0.0 & 11.7 & 17.3 \\
South Africa & 5.6 & 4.2 & 8.8 \\
Sudan & 4.6 & 3.0 & 43.9 \\
Tanzania & 40.9 & 9.9 & 12.5 \\
Uganda & 2.6 & 0.2 & 0.4 \\
Zambia & 0.2 & 3.6 & 5.3 \\
\hline
\end{tabular}

Source: IMF (ESDS International, University of Manchester), Direction of Trade Statistics and COMTRADE.

investment in Africa, particularly in East Africa where there were significant expatriate Indian communities. More recently, China has also taken an increased interest in the region, reflected in a number of major new investments. Some analysts predict that China will be one of the top three investors on the continent by the end of the decade (The Economist 2004).

\section{Exports from Africa to China and India}

The rapid growth of Chinese and Indian imports have offered market opportunities to exporters around the world and as was seen above, Africa has also benefited in terms of export growth. In this section, we turn to a more detailed analysis of the extent to which individual African countries have participated in this expansion and the types of products involved.

Table 1 shows that the extent to which African countries are involved in exporting to China and India varies considerably from case to case. In 2003 , exports to China were particularly significant for
Sudan (41 per cent of total exports) and Angola (23 per cent), but of the remaining 19 countries, only Somalia exported more than 5 per cent of its total exports to China. Exports to India were around 10 per cent or more of total exports for four countries, Senegal (13 per cent), Somalia (12 per cent) and Nigeria and Tanzania (10 per cent each). None of the other countries covered in this study exported more than 5 per cent to India.

What are the major types of products exported from Africa to China and India? Not surprisingly, given Africa's traditional comparative advantage and China's booming demand for energy and natural resources to fuel its industrial growth, the bulk of African exports to China are minerals, petroleum and timber.

Angola, Cameroon, Democratic Republic of Congo and Sudan are significant exporters of crude petroleum to meet China's demand for energy. Cameroon and Congo, along with Mozambique and Tanzania are exporters of wood, while Ghana, Namibia and Zambia supply non-ferrous base metals, which are important raw materials for 
IDS Bulletin 37.1 Asian Drivers: Opportunities and Threats

Table 2: Imports from China and India as a share of total imports, 2003 (\%)

\begin{tabular}{llll}
\hline & China & India & Total \\
\hline Angola & 3.5 & 1.5 & 5.1 \\
Botswana & 0.9 & 0.2 & 1.2 \\
Cameroon & 4.8 & 1.7 & 6.6 \\
Congo (Democratic Republic of) & 2.7 & 1.0 & 3.6 \\
Ethiopia & 6.4 & 3.2 & 9.6 \\
Ghana & 9.1 & 4.6 & 13.8 \\
Kenya & 6.4 & 5.8 & 12.2 \\
Lesotho & 2.2 & 0.5 & 2.7 \\
Malawi & 1.9 & 6.3 & 8.2 \\
Mozambique & 2.8 & 3.7 & 6.4 \\
Namibia & 1.9 & 0.3 & 2.3 \\
Nigeria & 7.1 & 2.5 & 9.7 \\
Rwanda & 1.1 & 1.6 & 2.7 \\
Senegal & 2.7 & 2.2 & 4.8 \\
Sierra Leone & 2.3 & 5.4 \\
Somalia & 3.1 & 9.7 & 10.7 \\
South Africa & 1.0 & 1.5 & 7.5 \\
Sudan & 5.9 & 4.2 & 18.5 \\
Tanzania & 14.2 & 7.6 & 16.7 \\
Uganda & 9.1 & 7.4 & 12.6 \\
Zambia & 5.1 & 2.2 & 5.0 \\
\hline
\end{tabular}

Source: Authors' own elaboration from IMF, Direction of Trade Statistics.

China's booming industrial sector. In all cases, the exports involve very limited processing within the African countries. The only exceptions to this are exports of iron and steel and steel products from South Africa. The only other product to feature significantly in China's imports from Africa is cotton from Cameroon, Sudan and Tanzania to supply the demand for cotton from the rapidly growing Chinese textile industry. China has not been able to meet the demand domestically because of the decline in the area planted to cotton as farmers switch to more profitable crops.

As can be seen in Figure 1, India's imports from Africa are now lower than China's and have been considerably less dynamic in recent years. The pattern of imports is not so clear cut either. Mozambique is important as an exporter of fruit and nuts to India as are Ghana, Nigeria and Tanzania. Sudan is primarily important as an exporter of cotton. Zambia and Tanzania export precious stones. Senegal has large exports of phosphoric acid, while South Africa's main export to India is gold.
It is likely that China and India will become increasingly important export markets for the African economies over the next decade. Rising incomes will also change the structure of demand in China and India. Increasing levels of per capita income will lead to a growing demand for food, particularly those with high income elasticity such as meat products, fish, fruit and beverages. The growing demand for meat in China has already led to increased imports of animal feedstuffs from Latin America in recent years. There may be new opportunities for other agricultural exports from Africa such as coffee and sugar. China and India's industrial production will also continue to expand, leading to further increased demand for raw materials and energy which already figure significantly among exports from several sub-Sahara African (SSA) countries.

There are several countries among the 21 included here which have so far developed very limited trade links with China or India. Botswana, Lesotho, Malawi and Uganda export less than 1 per cent of their total exports to the two Asian 
Table 3: Export Similarity Index (ESI) between exports of 18 African countries and China and India (\%)

\begin{tabular}{llll}
\hline & Year & China & India \\
\hline Botswana & 2001 & 5.8 & 20.1 \\
Cameroon & 2003 & 6.6 & 11.7 \\
Ethiopia & 2003 & 4.3 & 9.3 \\
Ghana & 2000 & 10.6 & 13.0 \\
Kenya & 2003 & 19.3 & 27.9 \\
Lesotho & 2002 & 17.8 & 13.0 \\
Malawi & 2003 & 10.6 & 12.4 \\
Mozambique & 2002 & 6.4 & 11.5 \\
Namibia & 2003 & 18.7 & 29.1 \\
Nigeria & 2003 & 1.7 & 0.8 \\
Rwanda & 2003 & 14.8 & 14.2 \\
Senegal & 2003 & 4.5 & 23.4 \\
Sierra Leone & 2002 & 27.7 & 4.8 \\
South Africa & 2003 & 2.6 & 40.2 \\
Sudan & 2003 & 11.0 & 10.1 \\
Tanzania & 2003 & 8.0 & 20.6 \\
Uganda & 2003 & 11.0 & 12.3 \\
Zambia & 2002 & & 17.3 \\
\hline
\end{tabular}

Source: Authors' own elaboration from COMTRADE data.

Note: Based on 2003 export data for China and India, and the latest available date for the African countries. Angola, Democratic Republic of Congo and Somalia were omitted because of the lack of three-digit SITC data on exports for any year from 2000 onwards.

economies, while Ethiopia and Kenya export less than 2 per cent (see Table 1). These may have unexploited export opportunities, which should be explored. This is supported by the analysis of the International Trade Centre, which identifies potential for increased exports from Ethiopia and Kenya to both China and India and from Uganda to India. ${ }^{2}$

\section{Imports from China and India}

As can be seen from Figures 1 and 2, African imports from China and India increased significantly from 1990 onwards and particularly since 1997. Table 2 shows that by 2003, there were six SSA countries for which China and India together accounted for more than 10 per cent of their total imports, namely Ghana, Kenya, Somalia, Sudan, Tanzania and Uganda. Two more countries, Ethiopia and Nigeria were just below the 10 per cent mark. If there are significant effects from imports from the Asian Drivers, they are most likely to be found in these countries.
Virtually all the exports from China to the main African importing countries are made up of manufactured goods. The vast majority of Indian exports to the region are also manufacturers with the exception of Somalia, which imported a significant quantity of sugar from India in 2003. Imports cover a wide range of manufactures and are not confined to labour-intensive products such as garments and footwear.

The growth of imports from China and India can have a dual effect. Where they compete with domestic production, they may have a negative effect on local manufacturers leading to reduced output, plant closures and job losses. On the other hand, the increased availability of cheap Chinese or Indian goods tends to reduce prices to the benefit of local consumers. While orthodox economics suggests that the gains in consumer welfare will outweigh the loss to producers in the long run, it has to be recognised that increased import competition may have negative impacts at least in the short term and, where structural rigidities 
Table 4: Proportion of exports facing competition from China and India (\%)

\begin{tabular}{llll}
\hline & Year & China & India \\
\hline Botswana & 2001 & 6.0 & 89.9 \\
Cameroon & 2003 & 23.8 & 5.6 \\
Ethiopia & 2003 & 17.8 & 7.6 \\
Ghana & 2000 & 32.3 & 7.5 \\
Kenya & 2003 & 33.8 & 25.4 \\
Lesotho & 2002 & 69.1 & 6.8 \\
Malawi & 2003 & 7.0 & 25.2 \\
Mozambique & 2002 & 5.4 & 16.7 \\
Namibia & 2003 & 2.0 & 18.4 \\
Nigeria & 2003 & 7.8 & 0.1 \\
Rwanda & 2003 & 44.1 & 30.2 \\
Senegal & 2003 & 5.4 & 32.7 \\
Sierra Leone & 2002 & 54.4 & 0.8 \\
South Africa & 2003 & 2.2 & 18.1 \\
Sudan & 2003 & 26.3 & 79.5 \\
Tanzania & 2003 & 35.5 & 13.0 \\
Uganda & 2003 & 82.4 & 2.2 \\
Zambia & 2002 & & 11.3
\end{tabular}

Source: Calculated from Financial Times, 19 July 2005, and Planning Commissiion (2004).

prevent rapid reallocation of resources, these may persist for a considerable period of time.

Of course if increased imports from China and India are mainly at the expense of other exporters, then the negative impacts on local producers will be much less and the net benefits from cheaper imports much greater. Some preliminary evidence suggests that, particularly in the case of China, increased imports have been mainly at the expense of imports from other countries, so that the effect on employment domestically was likely to be muted (Jenkins and Edwards 2005: Table 6.3). ${ }^{3}$

China will continue to expand its exports of manufactured goods to the African countries in the foreseeable future, as will India. As China upgrades its technological capabilities, it is likely to be competitive in a wider range of industries. This is only likely to be a threat to local producers in South Africa, with its relatively sophisticated industrial sector and much less so in other SSA countries.

\section{Competition in third markets}

Compared with some other developing countries, particularly those in South-East and South Asia which have specialised in exports of labour-intensive manufactures in recent years, it seems likely that
African countries would be less threatened by competition from China and India. As Wood (2002) has shown, African exports tend to be land/natural resource intensive rather than labour intensive. This suggests that for most African countries, the structure of their exports is likely to be quite different from that of China or India and unlikely therefore to face a competitive threat in third markets. On the other hand, recent reports from Lesotho that the elimination of Multifibre Arrangement (MFA) quotas has led to the closing down of a number of factories and the loss of almost 10,000 jobs shows that not all African countries are unaffected by Asian competition (Peta 2005).

A standard measure of the extent to which the exports of two countries are likely to compete with each other is the Export Similarity Index (ESI). ${ }^{4}$ Table 3 shows the Index between the exports of each of the 18 African countries covered and China and India, respectively using the latest data available. The Index can vary between 100 per cent when two countries have identical export structures and 0 when they do not have any exports which are common to both. Table 3 confirms the view that African countries generally have a rather low similarity of exports with China and India. ${ }^{5}$ As a 
point of comparison, the ESI between China and India was 40.8 per cent, which was matched only by that between South Africa and India. Estimates of the ESI between China and some other Asian countries for 2002 were considerably higher than those between China and any African economy. ${ }^{6}$

Although a low ESI indicates that two countries have very different export structures, where the countries have very different levels of exports, this is not a good indicator of the extent to which the exports of the small country faces competition. Because of the difference between the scale of exports from China/India and those of the African countries, an African country may face considerable competition from China/India in the world market for a product which accounts for a high proportion of the African country's exports, but this is not reflected in the ESI because the product accounts for a relatively small share of China/India's far more diversified exports. ${ }^{7}$

An alternative approach is to identify those products in which China and India are likely to be significant competitors in international markets and to see what proportion these represent of the exports of the African countries. In order to do this, Standard International Trade Classification (SITC) three-digit classes in which the share of China or India in world exports increased by 1 per cent or more between 1990 and 2002 were considered as products in which other countries were likely to face increased competition in third markets. ${ }^{8}$ China increased its world market share by this amount in 140 products, while India did so in 31 out of a total of 237 three-digit categories.

Table 4 shows the proportion of each country's exports which are in SITC three-digit categories in which China and India increased their share of the world market. These figures are likely to be highend estimates for several reasons. First, the level of aggregation may hide the fact that different products are exported from the African and Asian countries. Thus, for example, the very high share of Botswana's exports which face competition from India reflects the significance of exports of SITC 667 (pearls, precious and semi-precious stones). At a more disaggregated level, Botswana's exports are almost entirely of rough diamonds (66721) whereas India exports cut and worked diamonds (66729). Exports may also be directed to different countries so that African exports do not compete directly with those of the Asian countries. Thus a more careful analysis is required before definitive conclusions can be arrived at regarding the extent to which a country's exports is threatened by China or India.

In contrast to the ESI, the data in Table 4 indicates that for most countries, China represents a greater threat to exports than India. This is hardly surprising given that China has increased its share of world exports of far more products than India. It serves to reinforce the point that the ESI may not be a very good indicator of the extent to which a country's exports face competition.

Looking to the future, China will continue to be highly competitive in manufacturing. As the economy becomes more technologically sophisticated, it will broaden the range of manufactures in which it is internationally competitive. However, given the vast army of unskilled labour available in China, it is unlikely that such upgrading will lead to a withdrawal from exports of unskilled labour-intensive products. ${ }^{9}$ India, which up to now has not had the same impact on global markets for manufactured goods as China, is likely to become increasingly competitive in the future. Its exports are predicted to be concentrated in unskilled labour-intensive manufactures (Wood and Calandrino 2001).

Although the limited extent to which African countries have developed exports of labourintensive manufactures means that the immediate negative effects on production and employment of increased competition from China and India will be less than for some Asian countries, it may make it more difficult for them to develop such industries in the future. Given the important role played by sectors such as clothing and footwear in launching industrialisation in many countries in the past, this may prove a barrier to accelerating growth in subSaharan Africa in the future.

\section{Impacts on foreign direct investment}

As noted in the introduction, the growth of China and India could potentially have two types of impacts on FDI in other developing countries. On the one hand, there is a fear that the attraction which the Asian Drivers represent for foreign capital will lead to a diversion of investment from other destinations. On the other hand, there is recognition of the fact that China and India have begun to invest overseas themselves and may become an important source of capital.

The first question is whether the inflow of FDI 
Table 5: China and India's share in FDI stock in selected African economies

\begin{tabular}{|c|c|c|c|}
\hline & $\begin{array}{l}\text { Total inward FDI stock (2002) } \\
\text { (US\$m) }\end{array}$ & $\begin{array}{l}\text { Of which China } \\
\text { (US\$m)* }\end{array}$ & Share (\%) \\
\hline Cameroon & 1505 & 16 & 1.1 \\
\hline Ghana & 1610 & 19 & 1.2 \\
\hline Mozambique & 1505 & 15 & 1.0 \\
\hline Nigeria & 22,570 & 44 & 0.2 \\
\hline South Africa & 29,611 & 125 & 0.4 \\
\hline Tanzania & 2,335 & 41 & 1.8 \\
\hline \multirow[t]{2}{*}{ Zambia } & 2,241 & 134 & 6.0 \\
\hline & Total (2003) (US\$m) & $\begin{array}{l}\text { Of which India } \\
(\text { US } \$ m)^{*}\end{array}$ & Share (\%) \\
\hline Sudan & 4033 & 912 & 22.6 \\
\hline
\end{tabular}

Source: UNCTAD (2004a: 298-99) and CABC (2004: Table 2).

"Cumulative value of investment from China (1979-2002) in Nigeria, South Africa, Tanzania and Zambia, and from India (1996-2003) in Sudan. Value to the end of 2001 for China's investment in Cameroon, Ghana and Mozambique.

to China and India since 1990 has involved a diversion of capital at the expense of developing countries in Africa. There are two reasons why diversion might be more likely for FDI into China. One is that FDI into China is so much larger than FDI into India. The second is that FDI into China is much more strongly linked with export production and might be considered relatively footloose. In China, about two-thirds of FDI goes to the manufacturing sector and foreign affiliates account for half of exports (Gottschalk 2005: 10), whereas in India, foreign affiliates account for less than 10 per cent of India's manufacturing exports.

The case for diversion of FDI into both China and India is weak however, because much of the FDI in Africa is in search of natural resources and is therefore location-specific. Furthermore, FDI into India is to a considerable extent in information and communication technology (especially in Bangalore) (UNCTAD 2003), which requires an educated labour force. Finally, as we have seen, there is generally little competition in third markets between India and China on the one hand and African countries on the other. The conclusion is that, for sub-Saharan Africa in general, the diversionary effect of FDI inflows into both China and India is small.

The second question is how significant are FDI flows from China and India for the countries of sub-Saharan Africa. Unfortunately, there is only limited data available on the scale of such flows. FDI outflows from China and India have been small compared with the countries' inflows. Total annual FDI outflows averaged US $\$ 3$ bn from China and US\$1bn from India per year between 2000 and 2003 (UNCTAD 2004a: 24). The outflow from China between 2000 and 2003 was less than 0.5 per cent of the world total. China's stock of FDI held in other countries in 2003 was also less than 0.5 per cent of the world total and India's was even smaller (UNCTAD 2004a: 382). Thus both China and India have played a much smaller role in exporting FDI than in importing it and the conclusion is that the effect of outward FDI from China on developing countries in Africa has so far been slight, relative to the effects of trade.

However, given the lack of success of the region in attracting FDI generally, it is possible that the Asian Drivers are making a significant contribution to the total inflow to particular African countries. Table 5 provides a rough indication of the relative significance of China and Asia in relation to the stock of FDI in the countries where they have the largest investments. For most countries, FDI from China represents only around 1 per cent of the total stock, with the exception of Zambia where it is 6 per 
cent. Indian investment in Sudan however, is highly significant accounting for over one-fifth of all FDI. The share of the two Asian countries in the total stock may underestimate the contribution made by new inflows.

Oil is by far the most important sector of FDI into Africa from the Asian Drivers. India's major investment in the region is the state-owned Oil and Natural Gas Commission Ltd's stake in a Sudanese oil field (UNCTAD 2004b: 8). China's involvement in Africa is also heavily geared towards oil and it too has recently made a significant investment in Sudan (The Economist 2004). China has also invested in minerals in the region, particularly in the Zambian copper industry, and has some investment in manufacturing in the region including textiles in Nigeria, food and beverages in Ghana and electric appliances in Mozambique (CABC 2004). However, in general, as with trade, China and India's investment relationship with Africa is dominated by extractive activities.

The World Investment Report 2004 expects outward investment from China to increase as the government has relaxed restrictions on investment, partly to ease the pressure of rising international reserves on the exchange rate (UNCTAD 2004a: 20). The Government of China has recently expressed a strong political commitment towards Africa and has stated its intention to give preferential treatment on trade from the least-developed sub-Sahara African countries and, together with the UNDP, has established a China-Africa Business Council (CABC 2004) to promote trade with, and FDI in, Africa. Chinese FDI has grown rapidly over the four years up to 2002 with Africa representing 10 per cent of the total (CABC 2004: 4) and some commentators predict that China could be one of the top three investors on the continent within five years (The Economist 2004). These investments are likely to continue to be predominantly in natural resources.

Similarly, outward FDI from India is expected to grow rapidly as restrictions on FDI abroad are relaxed by the Indian Government (UNCTAD 2004b). In the recent past, India's outward FDI has been in the manufacturing and service sectors (UNCTAD 2004b). Such investment is unlikely to go to SSA but the pattern of India's outward FDI is widely believed to be changing. With India importing 70 per cent of its oil needs, securing natural resources is becoming an important driver for Indian outward FDI (Gottschalk 2005:13; UNCTAD 2004b). Thus FDI into SSA is likely to increase from both China and India, but most such investments are likely to be in oil and mining.

\section{Conclusion}

Although the impact of the Asian Drivers on subSaharan Africa has received much less attention than the impact of China on other Asian countries or on Latin America, this article shows that for some African countries these impacts are by no means negligible and are likely to become more important in the foreseeable future. The ways in which Africa has been affected differs from country to country. Some, such as Angola, Nigeria and Sudan, are important exporters to either China or India so that the major impact on them has been through the growth of exports. However, the most significant impact in Ghana, Ethiopia, Kenya, Tanzania and Uganda has been as a result of increased imports from China. Although the profile of exports from sub-Saharan Africa is very different from that of China, there are some countries which may suffer from increased competition from China in third markets. The most obvious example is Lesotho, but other countries such as Mozambique and Zambia may also be negatively affected.

This article has only been able to set out the main channels through which the Asian Drivers are having an effect on sub-Saharan Africa. There is clearly a need for more detailed research both on individual countries and at the level of particular value chains in order to trace through the impacts within Africa of the growing integration of China and India in the global economy. 


\section{Notes}

* This article draws on a report prepared by the authors for the Department for International Development (Jenkins and Edwards 2005). The views expressed in this article are those of the authors and should not be regarded as reflecting the views of the DFID.

1. The term 'Asian Drivers' is used to describe the two large, dynamic Asian economies, China and India.

2. The ITC website, www.itcen.org estimates trade potential using a model TradeSim, version 2 for a number of countries. Botswana, Lesotho and Malawi, the other countries mentioned here, are not included by the ITC.

3. This conclusion is derived from aggregate trade data. It is possible that for specific products or groups of products, imports from China have displaced domestic production. A more detailed analysis of the imports of the African countries at the product level or for groups of products would be required to explore this further

4. The ESI is calculated from the share of each three-digit SITC product in the total exports of each country. It is the sum of the minimum value of the share of each product. $\mathrm{ESI}=\sum_{\mathrm{i}} \mathrm{MIN}\left(\mathrm{X}_{\mathrm{i} 1} \mathrm{X}_{\mathrm{i} 2}\right)$ where $\mathrm{X}$ is the share of a commodity in exports, $\mathrm{i}$ is the three-digit industry and 1 and 2 are the two countries for which the index is being calculated.

5. Comparison of the two columns in Table 3 suggests that Africa's export structure is more like that of India than China.

\section{References}

CABC, 2004, Support to Establishing the China-Africa Business Council (CABC), Government of the People's Republic of China and the United Nations Development Programme

The Economist, 2004, 'China's business links with Africa: a new scramble', 25 November

Gottschalk, R., 2005, 'The Asian Drivers; financial flows into and out of Asia, and implications for developing countries', paper presented at the Asian Drivers' workshop, Institute of Development Studies, Brighton, 9-10 May

Jenkins, R. and Edwards, C., 2005, 'The effect of China and India's growth and trade liberalization on poverty in Africa', Enterplan/ODG, Report to DFID DCP70, Reading
6. The ESI with China was 47.0 per cent for Indonesia, 38.2 per cent for Vietnam and 31.6 per cent for Pakistan.

7. Most African economies' exports are concentrated in a small number of products, while the exports of China and India are far more diversified. For the products that an African country exports, the value entering the ESI is likely to be the share of that product in China/India's exports, which may be quite low, while for products that the African country does not export, the value will be zero. Thus, although China/India may be significant competitors in world markets for the products exported by the African country, this is not necessarily reflected in a high ESI.

8. The increase in China/India's share of the world market was chosen as a criterion, rather than the rate of growth of exports, to avoid the inclusion of products in which a high rate of growth reflected a very small initial share of world exports from China/India.

9. In the longer term, demographic change in China as a result of the one child policy and increased educational levels will mean that it will eventually lose its comparative advantage in labour-intensive manufactures but this is unlikely within the time frame being considered here.

Peta, B., 2005, "The "Chinese tsunami" that threatens to swamp Africa', The Independent, 25 April

UNCTAD, 2004a, World Investment Report 2004, Geneva: UNCTAD

UNCTAD, 2004b, India's Outward FDI; A Giant Awakening, UNCTAD/DITE/IIAB/2004/1, Geneva: UNCTAD

UNCTAD, 2003, World Investment Report 2003, Geneva: UNCTAD

Wood, A., 2002; 'Could Africa be like America?', proceedings of the Annual Bank Conference on Development Economics, April-May 2002, Washington, D.C.: World Bank

Wood, A. and Calandrino, M., 2001, 'When other giant awakens: trade and human resources in India', Economic and Political Weekly, January 